\title{
Colonialism and the Agikuyu Women Indigenous Knowledge Systems on Food Crop Production in Kiambu Kenya 1902-1918
}

\author{
Martha Wanjiru Muraya (Corresponding Author) \\ Department of Humanities, Chuka University \\ P.O Box 109-60400, Chuka, Kenya
}

Tel: 254-723-628-518Ｅ-mail: murayamartha@yahoo.com

Geofrey King'ori Gathungu

Department of Plant Sciences, Chuka University

P.O Box 109-60400, Chuka, Kenya

E-mail: gkgathungu@yahoo.com

Lazarus Ngari Kinyua

Department of History, Archaeology and Political Studies, Kenyatta University

P.O Box 43844, Nairobi, Kenya

E-mail: ngari.lazarus@ku.ac.ke

Received: May 8, 2019 Accepted: June 11, 2019 Published: June 25, 2019

doi:10.5296/ijch.v6i1.14975 URL: https://doi.org/10.5296/ijch.v6i1.14975

\begin{abstract}
The introduction colonial capitalist economic policies and practices such as land alienation, forced labour and commercial crop production acted as a major catalyst of change on the existing African indigenous subsistence production especially the Agikuyu Women's Indigenous Knowledge System (AWIKS). This research paper focused on examining the effects of European colonialism on the AWIKS on food crop production from 1902-1918. The study employed descriptive research design and historical trend analysis and it was done
\end{abstract}


in three sub-counties of Kiambu West, namely, Limuru, Lari and Kikuyu. Purposive and snowballing technique was used to get the respondents who were the bearers of the most relevant information. The main source of information was the corroboration of oral interviews, archival records analysis and secondary data. Oral interviews data were analyzed using Statistical Package for Social Scientists (SPSS) and reported using basic simple descriptive statistics. The Women and Development (WAD) theory helped to examine the nature in which the Agikuyu women were integrated in colonial capitalist economy, which explains their marginalization, subordination, oppression and dependency on men. The study found out that during the establishment of colonial rule the Agikuyu people were moved from their indigenous land and were pushed to poor, marginal and unproductive reserve areas where they did not have enough experience and accumulated indigenous knowledge system of the new agro-ecosystem. In addition, most of the drought tolerant food crops were neglected and others destroyed a move that may have led to underutilization of AWIKS on food crop production. This implied that the food supply was compromised and the society became more vulnerable to drought and famine. Therefore, in order to enhance food supply in the households some of the AWIKS on food crop production may be integrated into the modern western agricultural production practices.

Keywords: Colonialism, Capitalist economic system, Indigenous knowledge systems, Women, Agikuyu people

\section{Introduction}

Many Pre-colonial societies all over the world engaged in various productive and reproductive activities through experimentation. For many years, traditional peasant farmers managed the natural resources by selecting varieties of crops, farming methods and livestock breeds to cope with the environmental conditions and meet diverse nutritional and social needs. They developed a set of interaction between indigenous people's social-economic activities and ecosystem, which encouraged people to continuously rely upon nature for their livelihoods. These indigenous famers also developed Indigenous Knowledge (IK), which was guided by the local beliefs, customs and traditions. Therefore, IK encompassed the sophisticated collection of skills, innovations, practices, understandings and interpretations that guided traditional society in addressing local ecological limitations and maintaining a sustainable utilization and protection of natural resources (Brokensha \& Warren, 1980). The Indigenous Knowledge Systems (IKS) were transmitted and renewed by each succeeding generations, ensuring the wellbeing of people by proving food security, environmental conservation, and early warning systems for disaster risk management (Mafogoya \& Ajay, 2017). Traditional famers used IKS on food crop production as a key component in addressing the challenges of droughts and subsequently reduce their negative impacts (Chikare, 2018). These unique methods and practices that were used by the traditional societies were well established and developed out of the complex traditional channels of information and exchange within the community (Wright, 1994).

The indigenous knowledge systems on food crop production held by indigenous men and women differed according to their customary responsibilities (IFAD, 2009). Men and women often had different types of traditional knowledge related to their specific roles in food production and Agriculture. FAO also recognized the importance of women, men and youth 
as change agents in agricultural adaptation (FAO, 2017). Women in most traditional societies were more responsible for the food crop production and ensuring sufficient food in their households (Ashley, 2000). In many parts of Africa, as similar to other indigenous societies around the world, it was women who were primarily responsible for food production, household management and nurture of children. Consequently, they had more in depth knowledge and unique skills in food production practices. In food crop production, many traditional African women were the main custodians of seed diversity, which means selection, storing, breeding, enhancing, diversification, multiplying and exchanging seed, building on the knowledge they inherit from generations before them (Grey \& Patel, 2015). They also had in-depth indigenous knowledge system on variety of farming methods that ensured crops reached maturity and increased crop yield, and also various methods to enhance availability of food up to the next food crop harvest. Yonah \& Gaoshebe (2017) viewed that African women used the IKS as an effective resource to raise agricultural productivity and in the life of rural people and therefore a critical understanding the important role of men and women IKS in agricultural production need to be taken seriously by researchers, stakeholders and policymakers.

Musalia (2010) observed that in the traditional Agikuyu community, food crop production was also gendered. On one hand women were responsible for seasonal foods crops (irio cia Kimera) such as varieties of millet, sorghum, legumes (beans, cowpeas, green grams), vegetables, fruits which was labour intensive and required in-depth knowledge and skills while on the other hand, men cultivated certain perennial crops (irio cia menja) like bananas, sugarcane, yams and cassava, pumpkins, and gourds. These gendered food production roles and responsibilities determined decision-making, technology and tools, nature of knowledge, skills and practices in food crop production (Middleton, 1953).

This meant that the pre-colonial Agikuyu women were basically responsible for intensive food crop production activities which had to be performed daily or as seasonal routine. This heavy workload probably made the traditional Agikuyu women adapt to climate variability and ecological limitation using indigenous knowledge and skills. They possibly developed extensive knowledge of their natural environment, in predicting weather, interpreting the climate and weather change, knowledge in soil suitability and management, selection of quality seeds, proper methods of farming, crop protection and strategies of food crop storage, preservation and preparation. Therefore, they played an important role in managing natural resources for domestic food crop production, to improve their livelihoods and to develop their community.

Although African women were the major food producers in their pre-colonial communities, these women's indigenous knowledge systems were not given due consideration during the establishment of European colonial rule and in the implementation of the Europeans capitalist commercial production in most African societies. The women's indigenous knowledge system on agricultural production was viewed as backward, primitive and agricultural practices that were not economically viable. According to Zeleza (1993), most of the European colonizers and Western historiographers of the nineteenth and early twentieth Century described African indigenous practices and knowledge as "simple", "primitive", and "outdated". However, this was a wrong assumption, which may have been guided by the 
European modernization ideology that was meant to draw Africans into the international capitalism. Hence, they were slowly pushed to the periphery to pave way for the European modern commercial agricultural production. African indigenous knowledge system had never been "simple" or "static", but has been evolving slowly in response to increased ecological changes. However, drastic changes and marginalization of the indigenous subsistence food crop production practices became evident when the European colonial government attempted to promote and legalize European acquisition of African land, forced labour and commercial food and cash crop production.

It is important to note that although both African men and women's indigenous knowledge system on food crop production was highly disregarded by the European colonialists. However, land alienation, forced labour policy and commercialization of agriculture during the colonial period to a larger extent limited women's access to main production forces (land and labour) and also caused heavy burdens on their labour (Staudt, 1993). The European perception of the role of women was guided by the $19^{\text {th }}$ century European Victorian ideology of separate spheres that presented women as good mothers, wife and a house maker (Mies, 1986). This assumption compromised women's capacity to participate in the public sphere and therefore the capitalist competition, wage labour, commercial crop production and politics was continuously viewed as a difficult sphere for men (Turner \& Katherine, 2006).

In Kenya, the colonial pressure on African's indigenous practices was probably felt in the first two decades of European settlement when the colonialists introduced several ordinances and socio-economic policies. This started with the introduction of the Land order-in Council of 1901 and the Crown Lands Ordinance of 1902, which provided the settlers with 99 years lease and each settler was given 160 acres free of charge as an inducement to farm. This perhaps had far reaching implications on the Agikuyu women subsistence agriculture. These orders gave the colonial government jurisdiction over all lands previously occupied by Africa. Specifically, the Crown Lands Ordinance of 1902 gave the commissioner power to lease or sell land to settlers and to define the conditions of land alienation (Tignor, 1979; Sorrenson, 1967).

Following the signing of the Crown- Land policy into Law in 1902, there was a significant influx of the number of European settlers and the missionaries into the protectorate through the invitation extended by Sir Charles Eliot (Leys, 1975). Given the strategic location of the Kiambu area, the fertility of the soil for agriculture presented there, refreshing climatic conditions and hospitality of the Agikuyu community, there was of immense attraction between the Europeans and the Agikuyu people of Kiambu. The colonial government felt comfortable to establish agricultural estates and training institutions in Kabete, Kikuyu and Limuru areas of Kiambu (Rosberg \& Nottingham, 1966). When most of the Europeans arrived in Kiambu in the early 1900s, they found when the Agikuyu people were desperate due to famine, diseases and other epidemics and most of the land was unoccupied. Therefore, that can also explain the willingness of the Agikuyu people to welcome any kind of help from the foreigners. The Europeans embarked on alienation of large tracks of land in Kiambu in order to establish cash crop plantations which also required them to introduce ways to force the Agikuyu people to seek labour in the European farms and plantations. The period between 1903 and 1918 was also one of the expansion of settlers' commercial food and cash crop 
production (Huxley, 1968).

This establishment of European's policy of supremacy through intensive land alienation, forced labour, and introduction of commercial large-scale cash crop farming may have had considerable implications on the Agikuyu women's indigenous knowledge systems on food crop production and some effect on the availability of food in the households. Therefore, this research paper focused on the historical analysis of the implications of the establishment of colonial capitalist commercial production on the existing AWIKS on food crop production from 1902 to 1919. By so doing, it contributes highly to the wider understanding of economic history with specific attention to history of agriculture in Kenya. It also addressed significant policy concerns with regard to the important role of IKS on food crop production and the role of African women in food crop production.

\section{Literature Review}

The dynamic interaction between peasants' food production and commodity production under the European capital penetration in Tanzania neglected traditional drought tolerant food crop leading to increased food shortage and famine during the colonial period (Bryceson, 1980). This was probably because although African women were the major food producers, they were excluded from land ownership in the colonial and post-colonial period which only worsened the food shortage situation. The creation of a wage labour and the reorganization of African labour that developed during European settlement in Kenya created a new constraint upon the African population (Wolff, 1974). This was due to limitation of their land in the reserves and the shifting of African labour for Europeans. Although these writers have not discussed specifically on AWIKS on food crop production, they gave a general understanding of impact of British imperial policies in Kenya between 1870 and 1930.

Olenja (1991) and Nasimiyu (1985) while examining the effect of introduction of inedible cash crop and migrant labour on food crop production in Kenya reported that the world economy disrupted the African society's division of labor, which denied the traditional households labour force. Women were left behind and they took over the tasks that were previously done by their male counterpart, which left them overburdened and marginalized. Further, Brett (1973) explored the nature of the connection between colonialism and underdevelopment. He viewed underdevelopment from the relation between the capitalist and pre- capitalist modes of production. According to him, capitalism created an economy characterized by massive and growing inequalities. These writes use underdevelopment theoretical approach to generally explore the nature of integrating Africans in European colonialism but the current study uses Women and Development (WAD) theory to specifically look at the nature in which the African women were integrated into colonial capitalist economy.

Omwoyo (1990) examined the organization and transformation of agriculture among the Gusii during the colonial period and stated that it was based on the indigenous knowledge and mastery of their environment. He argues that the colonial capitalism and the economic system modified, marginalized and subordinated the Gusii pre-colonial agricultural system. Similar observations were made by Esese (1990), who argues that the Wanga community of Western Kenya had efficient, self-sufficient and dynamic agricultural system prior to the establishment of colonial rule in Kenya. These two writers discuss how the pre-colonial 
agricultural productions in other Kenyan communities were subordinated by the European colonialists. This gave the current study valuable insight on how colonial policies disrupted pre-colonial agricultural systems in other Kenyan communities.

Likewise, Warren et al.(1989) documented the role of nineteenth century colonialism and social science in ignoring the indigenous knowledge, however, they pointed out that studies that depicted local communities and their knowledge as primitive, simple and static are now countered by a rapid expanding research that describes the complexity of many indigenous natural resources. Mafongoya \& Ajayi (ed), (2017) stated that the primary concern of European settlers was not to understand other indigenous knowledge systems per se, but rather to gather from the indigenous knowledge information for the development of colonial science and help in achieving their capitalism interest. The current study examined how the AWIKS on food crop was disrupted by the establishment of colonial rule in the first two decades. Furthermore, Kitching (1980) examined the impact of colonialism and imperialism on a number of Kenyan societies and traced the development of classes and economic change in Kenya between 1905 and 1970. He identified a number of changes and adaption that pre-colonial economy underwent after 1905 especially in Kikuyu land and in Nyanza province. Although this author did not say much about the African women's indigenous knowledge in those societies, he gave a general understanding of how colonialism interacted with indigenous societies the resulting inequalities and imbalance of such interactions. This study tackled the Agikuyu women involvement in such systems.

Kanogo (1993) reported that the establishment of colonial rule in Kenya and attempt to turn the country into a white settlement had a profound effect on the local African population because African land was alienated for European settlers' occupation and many Africans were dislocated into squatter land. she gave an example of Kiambu- Limuru areas where about 60,000 acres of Kikuyu land was alienated between 1903 and 1906 and by 1933, about 109.5 square miles of highly fertile kikuyu land had been alienated for European settlement, by 1910 there were about 11,647 Agikuyu people working on the Kiambu settlers farms. In addition, Kanogo (2005) observed that the European colonialists found the Agikuyu women practicing traditional indigenous knowledge system to ensure food crop production for continuous food supply in their households. However, the settler's plantation and mixed farming created a demand for a large number of wage labourers which indeed affected the Agikuyu indigenous division of labour. The current study went a step further to find out specifically the implications of European land and labour policies on the AWIKS on food crop production and how it affected food supply in the households.

\section{Theoretical Framework}

This study used Women and Development (WAD) theory (Rathgeber, 1990) which draws its ideas from Neo-Marxism and dependence theory. The Women and Development approach emerged as a critique of the Women in Development (WID) theory in the second half of the 1970s. WAD scholars were influenced by dependence theorists whose focus was on the role of external forces such as colonialism and imperialism in changing and weakening Africa's indigenous socio-economic and political institutions for their capitalist interests. They emphasized that colonial capitalism limited women's access to public wage labour, limited their access to land and land use practices and they also were treated as second-class citizens, 
thus, their traditional status was significantly disrupted and perhaps declined considerably and their bargaining power compared to that of men (Boserup, 1970; Pala, 1981). This was particularly acute in Africa and other areas where traditional female indigenous farming systems and food crop production was predominated (Peet \& Hartwick, 1999). Therefore, during the First World Conference on Women (FWCW) in Mexico City organized by UN in 1975, the Neo-Marxist feminists came up WAD approach to the study of women (Visvanathan, 1997).

The study adopted the Women and Development (WAD) theory as proposed by (Rathgeber, 1990). WAD perspective argues that women have always played an important role in the economies of their societies as both productive and reproductive actors but it was how they were integrated into global capitalism by the core countries that explains their marginalization, subordination, oppression and dependency on men. The European colonialism emphasized on the Western patriarchy social structure that separated the private and public domains assigned to women and men respectively. This compartmentalization of social structure was aimed at making the colonial capitalist ideology work for the Europeans, but its patriarchal stereotype ignored many African women's institutions. Rathgeber (1990) also that WAD accepts women as important actors in the economy of their own societies and their work as central to the maintenance of their societal socio-economic structures. It was for this reason that Rathgeber (1990) suggested that there was an urgent need to give equal value and recognition to both women and men distinctive roles through the use of WAD approach to development agenda especially in agricultural production because women undervalued roles are vital for economic growth of their societies. WAD theoretical framework was very useful in this study, it helped in examining the nature in which the Agikuyu women were integrated in colonial capitalist economy with the view that the integration of the Agikuyu women in the colonial capitalist economy only served to reinforce and strengthen the existing structures of inequality in the society.

\section{Research Methodology}

\subsection{Location of the Study}

The study was carried out in the Kiambu County, which was initially referred to as Kiambu district during the Colonial period. The County is in Central Kenya and is mostly inhabited by the Agikuyu people who are agriculturalists. According to the Kiambu County Integrated Development Plan (2013-2017), Kiambu County covers an area of about 2,543.5 $\mathrm{km}^{2}$ and it comprises of 10 Sub-Counties namely: Lari, Ruiru, Kikuyu, Limuru, Githunguri, Thika East and Thika West, Kiambu, Gatundu North, Gatundu South (Appendix 2). According to the Kenya National Bureau of Statistics (KNBs), the Kenya Population and Housing Census (KPHC) of 2009 indicated that the County's population was 1,602,754 comprising 791,494males and 811,260 females (KNBS, 2015). The study was conducted in three selected Sub-Counties of Kiambu West (Lari, Limuru and Kikuyu) that are in the upper highland (ASDSP, 2013). These three sub-counties were selected because they had very attractive agro-ecosystem that made the Europeans to settle and interact with the Agikuyu people in this region earlier than other areas of Kiambu upper highlands. 


\subsection{Research Design}

This research used descriptive research design, Kothari (1985) states the purpose of descriptive research is to give narrative descriptions of the state of affairs as it existed. Descriptive research design sometimes utilizes elements of both qualitative and quantitative research methodology (Glass \& Hoskins, 1984). This design enabled this study to organize data into common frequent patterns that emerged during data analysis, then those patterns were used to give an in-depth descriptive analysis of the situation as it existed during the first decades of colonial rule in Kiambu.

\subsection{Target Population}

The whole of Kiambu County had a population of 1,602,754 people while the subject of the study was drawn from a total of 375,781 people in three sub-counties of Kiambu West (Lari Sub-County's had 122,610 persons, Limuru had 129,609 persons and Kikuyu had 123, 562 persons). The respondents were drawn from people who were aged 65 years and above, in Lari Sub-County there were 4,306 persons, Limuru had 5,058 persons who were 65 years and above, and Kikuyu had 5, 683 aged 65years and above (KNBS, 2015). Therefore, the total targeted population of people aged 65 years and above was 15,047 people from the three Sub-Counties. This group of the population was very important since they were the bearers of most relevant information to the study.

\subsection{Sampling Procedures}

Due the expansiveness of Kiambu County, it was necessary to narrow down the area into a manageable research area. Kiambu County had 10 Sub-Counties and the study sampled three sub-counties from Kiambu West that is; Kikuyu, Limuru and Lari. The three Sub-Counties were sampled purposively on the ground that they had high colonial penetration than the rest of Kiambu. They are located in the Upper Highland zone which was highly fertile, with plenty of rainfall and proximity to Nairobi that provided an environment attractive to the Europeans settlement earlier than other areas of Kiambu.

The study also used non-probability sampling procedures and techniques which included purposive sampling and snowballing or chain sampling technique to identify the respondents who were the bearers of the most relevant information were interviewed.

\subsection{Sample Size}

The Sample size was based on the minimum sample size recommended by Kathuri and Pals (1993) in the table of population sizes with their corresponding sample sizes. In case of the three sub-counties of Kiambu (Kikuyu, Lari, Limuru) that have approximately a total of 15,047 people aged 65 years and above (KEBS, 2015), the table suggests that a universe population size of 15,000 , at the confidence level of $95 \%$ and sampling error of $5 \%$, the recommended sample size is 375 . However, not all the respondents in the recommended sample size by Kathuri \& Pals (1993) were interviewed because the researcher also applied the concept of data saturation in an interview-based research. The concept of data saturation states that when all important themes, experiences and perceptions are uncovered in an interview-based research, the information reach saturation and begins to be repetitive meaning that it is unlikely that conducting more interviews will reveal new information 
(Donna, 2013). Thus, during the study the oral data reached saturation at $68^{\text {th }}$ interview and the justification of a sample size of 68 respondents as reliable was supported by Miller (2012).

\subsection{Research Instrument}

\subsubsection{Interview Guide Questionnaire}

Data was collected using in-depth face to face interview for key respondents which had two sections. Section A covered the demographic data of the respondents, Section B had questions on implication of colonial land alienation, forced labor and large-scale cash crop production on the AWIKS. The interview guide questions consisted open ended and closed ended questions, since this was a historical study that endeavours to reconstruct the past, it relied on respondents' firsthand account and second-hand account of events that took place during the first two decades of colonial rule in Kenya.

\subsection{Data Collection Procedure}

In examining the implications of colonial policies on the existing AWIKS on food crop production from 1902 to 1918 , in-depth oral interviews were conducted with the help of research assistants. Where the respondents were not available to give oral information especially, in-depth archival records analysis was conducted and secondary data from books, theses, dissertations, journals, periodicals, seminar and conference paper, public documents and official records, local dailies, magazines and electronic information from various libraries and documentary centers.

\section{Findings and Discussions}

\subsection{Implications of Colonial Land Alienation on the AWIKS on Food Crop Production}

The Agikuyu Land tenure system prior to 1902 was under the githaka system or the sub-clan holdings (Mbari) where each clan established ownership under a specified portion of land. However, the establishment of the European settlement in the Kiambu in 1902 meant that such communal sub-clan or githaka land tenure system would be disrupted. Within the five years of the initial establishment of European settlement in Kiambu, the land tenure system was significantly altered (McGregor, 1996; Leys, 1973). The traditional land ownership was significantly affected by the White settlement in the Kiambu implying that also the traditional food crop production practices were equally disrupted.

Sixty two (91\%) respondents stated that when the white settlers settled in Kiambu the land was very scarcely cultivated and most of it was community's forest land where the neighboring Maasai community used to graze their cattle. Fifty $(73.5 \%)$ mentioned that after the white men identified the fertile land, they immediately put a demarcation around that area enclosing it to make it their private property. In addition, there were also small but an increasing class of Agikuyu people who consolidated the Agikuyu landholdings and collaborated with the colonial administrators. Thirty two (47\%) of the respondents mentioned that the Agikuyu people's traditional land use right was changed significantly because the Europeans fenced the land that was previously being used by the Agikuyu people for food crop production, grazing, land for community forest and for religious purpose (Table 1). 
Table 1. Effect of European settlement on traditional land ownership system

\begin{tabular}{|l|l|l|}
\hline Effect on land ownership & Frequency & Percent \\
\hline Land demarcation and Consolidation of Agikuyu landholdings & 50 & 73.5 \\
\hline Change of traditional right to land use & 32 & 47 \\
\hline Loss of their traditional fertile land & 62 & 91 \\
\hline Total interviews conducted & 68 & 100 \\
\hline
\end{tabular}

The settlers slowly demarcated the land, cut down some of the indigenous trees and bushes to build their houses and to pave way for a fertile piece of land to cultivate (Waller, 2012). The Agikuyu people and some of the Maasai pastoralists were pushed to the Northern edge of Kiambu West near Aberdare and Lari forests. Others were pushed to far edge of South-West land of Ndeiya which was a semi-arid plain covered by Lava and volcanic dust (KNA/MA1/7/12, 1903). This change in the traditional land occupation and land rights had some effects on the Agikuyu indigenous food crop production systems particularly the AWIKS on food crop production. When the Agikuyu people were pushed to the Aberdare and Lari forest edge, it was too cold to support sufficient growth of the Agikuyu indigenous food crops production. The semi-arid plain of Ndeiya and Karai area of Kikuyu had volcanic soil and rocks that were unsuitable for sustainable growth of their indigenous food crops and this may have led to neglect of some of the AWIKS in food crop production. Geographic variability in climate together with low levels of coping and adaptive capacity resulted in high levels of vulnerability for marginalized subsistence farmers (Biggs et al. 2018)

In line with the respondents' observations, Elkins (2005) pointed out that many Europeans especially the settlers wanted to farm in Kiambu because the land was ideal for coffee growing. They initially acquired 640 acres of the land per person as it was provided for in the Crown Land policy of 1902 but this was soon expanded to 1,000 acres of land per person while some acquired more land using the names of their children, wives and other relatives. It is estimated that between 1903 and 1905, about 60,000 acres of land were alienated in Kiambu-Limuru area displacing approximately 11,000 people, while Kanogo observed that following the crown-land ordinance of 1902, by July 1910, there were 11,647 Kikuyu on Kiambu settler farms as squatters and that majority of these Squatters were the original owners. Some of the land was alienated for the missionaries as well as for use by the government (Sorrenson, 1967; Kanogo, 1993). Furthermore, Overton (1987) reported that by 1920, three (3) million hectares had been alienated to the whites and another 1.3 million hectares taken as forest resource. African Natives were separated from their indigenous productive land resulting to social disintegration due to large-scale migration and resettlement of the Natives (Alila, 1977). Thus, they found themselves displaced and deprived of their traditional livelihoods and of access to their natural environment arable lands and forest resources (Jacquelin-Andersen, 2018).

Consequently, many Africans especially the Agikuyu of Kiambu had to vacate their traditional land and look elsewhere for a source of livelihood and were pushed to the squatter land and in reserves (Njehia O.I, 2017). Those who were settled in the reserves had their families with them and obtained a grazing room for few cattle (KNA/MA1/7/13, 1903-1911). 
Many people found that when they tried to return to their traditional land in order to resume their previous way of life, it had already been leased out to the settlers and they no longer had access to it (Jacquelin-Andersen, 2018). The Agikuyu women were displaced from their indigenous food crop gardens/plots a move that marked the beginning of serious disruption of their Indigenous skills and knowledge in food crop production and lack of coherent transition of their indigenous knowledge system from one generation to another (Kinuthia O.I, 2017; Njehia O.I, 2017).

The findings of this study show that the AWIKS in food crop production was greatly affected by the colonial land alienation. Fifty one (75\%) of the respondents observed that when the European alienated the Agikuyu indigenous land, they cleared everything that was in that land destroying even the Agikuyu food crops such as sweet potatoes and grains. In addition, $32(47.1 \%)$ and $60(88.2 \%)$ of the respondents mentioned that when the Agikuyu were moved from their indigenous fertile land where they used to grow their indigenous food crops, they lost coherent in use of AWIKS. Transmitting the knowledge and skills from one generation to another was disrupted because the Europeans did not recognize or give attention to the use of AWIKS in food crop production. Further, Sixty three $(92.6 \%)$ of the respondents stated that the Agikuyu did not have enough experience with the environment and understanding of natural resources around those new reserve areas, in forest margin near the edge of Mau escarpment, Aberdare forest and far in semi arid Maasai land where they were pushed to (Table 2).

Table 1. Effects of European land alienation on AWIKS

\begin{tabular}{|l|c|c|}
\hline Effects & Frequency & Percent \\
\hline Destruction of Indigenous food crops & 51 & 75 \\
\hline Lack of coherent use and transmission of AWIKS & 32 & 47.1 \\
\hline Restriction to smaller pieces of land & 53 & 77.9 \\
\hline Lack of enough soil variety & 42 & 61.8 \\
\hline Displacement of their indigenous food crop gardens & 60 & 88.2 \\
\hline Lack of experience with New ecology of squatter and reserve land & 63 & 92.6 \\
\hline Confiscation of indigenous farming tools by Europeans & 23 & 33.8 \\
\hline Reduction of value of women's food crop products & 20 & 29.4 \\
\hline No significant change & 14 & 20.6 \\
\hline Total interviews conducted & 68 & 100 \\
\hline
\end{tabular}

The Europeans also allowed their cattle to trespass on the reserves and squatter land eating up the food crops that women were growing in their small plots in the reserves. One of the respondents (Muraya O.I 2017) claimed "The Europeans were being asked to keep their cattle at home but they never gave attention to whatever they were being told". Hobley (1967) \& Waller (2012) further observed that in the initial stage of settlement in the squatter and reserve land, the squatters were not entirely detribalized. Those of the first generation of squatters or initial land owners in squatter land continued fairly well with their traditional 
agricultural practices, they remained in touch with the Agikuyu traditional culture and agricultural practices, however, when the new generation of the Agikuyu Squatters reached adult age, extra land was required. Land alienation posed more challenges and difficulty in practicing the traditional agricultural practices in the squatter land because the land for cultivation was continuously decreasing and the demand for food crops by squatters was increasing (Yonah \& Gaoshebe, 2014). This implied that traditional agricultural practices and labour networks would decrease, resulting to minimal use of Agikuyu women's indigenous food crop production. It also led to continuous soil exhaustion and nutrient depletion which ultimately adversely affected food crops yields (Wanjugu, O.I 2018).

Hobley (1910) also stated that the Agikuyu people were forced into poorer lands and this led to severe problem of overcrowding in reserves as they were confined to environments they were not used to managing before. The reserves consisted of marginal lands of low productive capability (Waller, 2012). Therefore, in the areas where the Agikuyu women had recently migrated from quite different ecological zone probably they did not have a good understanding of the new environment thus it became increasingly hard to use their indigenous knowledge in observation and prediction of weather variation; hence their traditional seasonal food crop production calendar was highly disrupted.

Agikuyu women may have had very little idea of nature of type of soil in the new ecological areas and how to manage the variety of soils they found so that they could increase the yield of their indigenous food crops. Furthermore, since certain pieces of traditional land were associated with the growth of certain crops, they realized that the soils and extreme cold or dry weather conditions in the new areas could not sustain some of the indigenous cereals, and legumes and so they abandoned them. This meant that the failure to know which indigenous grains or food crops were suitable in such new areas, the appropriate time to plant and how to manage the soil probably made the AWIKS in food crop production dormant and some were lost.

The loss of indigenous land also meant that women lost of access and authority over it. Indeed, 23 (33.8\%) observed when Agikuyu women tried to access traditional plots to remove or to harvest their food crops, the white Europeans confiscated and threw away the women's indigenous farming tools such as the digging sticks and baskets (Table 2). According to Gachihi (1986), the land alienation and the existing economic pressure played a significant role in reducing the economic independence that was enjoyed by the Agikuyu women prior to European colonialism. As colonialism continued to entrench itself in African soil, the perceived importance of women's agricultural contribution to the household was reduced as their vital role in food production was overshadowed by more lucrative male-controlled cash crops (Gachihi, 1986). The trauma of colonialism, discrimination, and the difficulties the indigenous people faced in trying to protect their indigenous land and traditional knowledge, forced them into unsustainable and desperate situations (Jacquelin-Andersen, 2018).

Therefore, the colonial land alienation was detrimental to the progressive development of AWIKS and skills as they were subjected to strong external pressure and in extreme cases 
destroyed which led to absolute poverty, and overcrowding. The colonial land alienation aimed at keeping Africans under proper control in order to safeguard the settlers' interests (KNA/MAI/I/7, 1914-1915).Once segregated from whites, the colonial government pressed natives to adapt western agriculture aimed toward meeting market demands and financial gain to support the cost of British colonial administration (Waller 2012, Alila 1977). Therefore, the Agikuyu people were left with no alternative other than to seek wage labor in settlers' farms and government public work service.

\subsection{Implication of the European Forced Labour on AWIKS in Food Crop Production}

The alienation of large tracts of Kiambu required Europeans to introduce ways to stimulate Africans to seek labour in European's farms. The main objective of the European colonialist was to ensure that Africans served their role in the colonial economy as supplies of cheap labour. European settlers believed that the native labour was as necessary in the development of the land as rain and sunshine. Indeed, they forced the local Chiefs and headmen to recruit labour for settlers' farms and for public works. According to a report by the Native Labour Commission 1910-1912 (KNA/MA1/12/4, 1912-1913) the commission stated that Chief Kinyanjui was one of the main recruiters of labour for the settlers in Kiambu area and in Fort Hall chief Njiri was used by Europeans to obtain labour recruits from Africans in the reserves. They introduced constant pressure to keep wages low and increased taxation. They consistently gave orders to the chiefs to recruit laborers by force. On the same note, Hollis the then Secretary for Native Affairs recounted how African laborers were recruited by force. $\mathrm{He}$ says the Europeans took advantage of the shortage of land to force the Africans lobour. They paid them very low wages, increased taxes and subjected them to very poor living conditions (KNA, PC/PC/8/5/1, 1912-1913).

Some of the respondents lamented that the Europeans got forced labour from the Agikuyu people by paying them low-wages, discouraging them from growing their own cash crops, introduction of heavy taxes. They also introduced identification pass of 1918 and stimulated them to acquire new needs/ wants that would compel them to seek labour (Wamoro wa Nderi O.I 2017 \& Wangari O.I 2017). Kanogo (1993) reported that the first labour recruits from Kikuyu land by the settlers were promised large tracts of land for grazing and cultivating and this was a sound footing that helped them to start acquiring Agikuyu labour without a lot of resistance. Later, a payment for hut tax was introduced in 1901 and it was paid in form of labour in order to force the Agikuyu to provide labour in European farms. However, from 1910 when poll tax was introduced, all male over 16 years were required to pay a poll tax in form of three rupees per month (Clayton, 1970).

Following the introduction of colonial labour laws, there was a mass movement of African labourers particularly men from the reserves to settler farms and urban areas in search of wage employment. However, since they could not meet their basic needs and pay the required taxes, they were forced to maintain economic links with the rural reserves. Mcgregor (1927) gives a vivid description of the inhuman treatment and abuse experienced by African labourers in the European settlers' farms. These ranged from physical beating and whipping, to denying them their wages and all adult male were required by the Native Labour 
Ordinance to be registered and carry a registration card or Kipande whenever they moved. This was meant to prevent Africans from deserting their employment without being traced and punished. According to the District commissioner's annual report, there were a total of 40,000 men registered labourers by 1922 (KNA/MA1/12/17, 1922).

The colonial labour laws directly affected the Agikuyu women because they were also required by law in some cases to provide wage labour for European plantation. The governor Northey Circular in 1918-1919 directed the District Officers and African chiefs to procure women and juvenile labourers for private and public works. The Northy Circular of 1919 was particularly used to get women into wage labour (Dilley, 1966; Sorrenson, 1967). The imposition of the colonial labour policies definitely altered the traditional division of labour on food crop production in two major aspects.

Sixty one $(89.7 \%)$ of the respondents mentioned that most Agikuyu women spent a lot of their time and energy in forced European cheap labour which was very tedious and in the evening they were completely exhausted and so they could hardly concentrate on using indigenous knowledge in their role of food crop production. Furthermore, 40 (58.8\%) of the respondents pointed out that the European forced labour overburdened Agikuyu women because most of Agikuyu men were forced to seek migrant labour employment in European plantation and in urban centers. This took away the Agikuyu men from traditional labour responsibilities they used to have in food crop production (Table 3).

This change in women traditional roles had immense implications on the AWIKS in the sense that the Agikuyu women were forced to move away from their homes for long hours or long period of time in order to supplement their family income. Consequently, they lacked enough energy and time to concentrate on their own food crop production or to utilize fully their indigenous knowledge and skills on food crop production. In explaining how lack of enough time affected the AWIKS on food crop production, $61(89.7 \%)$ of the respondents stated that due to lack of enough time to concentrate, many young women were not able to learn the indigenous techniques systems such as weather observation indicators, selection of quality seeds for planting, suitable soil variety, best farming methods to increased crop yield, harvesting time and the masterly of the traditional seasonal calendar from their elder generation (Table 3).

Table 3. Implications of colonial forced labour on Agikuyu women's indigenous knowledge system

\begin{tabular}{|l|l|l|}
\hline Aspect & Frequency & Percent \\
\hline Lack of enough time to properly use IKS & 61 & 89.7 \\
\hline Women overburdened leading to neglect of some AWIKS & 51 & 75 \\
\hline Compromise women's well being & 49 & 72.1 \\
\hline Exclusion of women from wage labour, low wages \& taxes & 22 & 32.4 \\
\hline Total interviews conducted & 68 & 100 \\
\hline
\end{tabular}

Consequently, the indigenous knowledge system may have been adversely disrupted since 
they were no longer applicable in the Europeans plantations. The cohesion and continuity of the indigenous knowledge system transmission from one generation to another was also greatly disrupted neglected. Furthermore, since many Agikuyu women did not have much experience with weather and climate variation in their new working stations, squatter land and in the reserves, the use of traditional Knowledge and skills was minimal and challenging and even sometimes they were using guesswork (Wangari, O.I 2017).

Agikuyu women were deeply affected by the Colonial directives on labour recruitment. Europeans demands for women labour were most intensive during the peak labour requirement on their Limuru tea, Kabete and Kikuyu coffee plantation (KNA, $\mathrm{AR} / 275 / \mathrm{KBU} / 10 ; 8)$. Women were major source of casual labour during the tea and coffee harvesting period and according to a report by Kiambu District Commission the intensive work of harvesting coffee was mostly being done by the women and children (KNA/MA1/12/14, 1918-1919; Presley, 1992). This exhaustive woman involvement in colonial wage labour may have made it increasingly difficult for the Agikuyu women to continue with normal traditional way of life especially the use of indigenous knowledge and skills on food crop production because of time limitation and being overburdened (Kanyuira, O.I 2017).

The introduction of forced wage labour also affected the Agikuyu women through the withdrawal of male labour from the traditional subsistence food crop production. Grey \& Patel (2015) trace the marginalization of indigenous women within their own communities to deliberate erosion of indigenous men's productive activity on the land. Kinoti (1983) \& Gakuru (1992) observe that the men who were forced to leave their home to seek wage labour settler farms and in urban areas received very little wages that could hardly sustain their basic needs and enable them pay taxes. Therefore, majority of men were forced to rely on foodstuff supply and support from their wives and children back in the reserves. Women in the reserves worked under pressure to meet the demand of European settlers' cheap labour and at the same time they were expected to continue with food crops production in their small plots in reserves or squatter land in order to sustain food supply required by their male migrant laborers (Wamoro wa Nderi, 2017).

With such immense workload, the Agikuyu women had less time to keep the shambas (farms) clean and attended especially those that had labour intensive crops such as Sorghum, these crops either rotted on the stalk or sprouted before it could be harvested (KNA/ AR/1916-1917:1). Mbilinyi (1985) \& Gailey (1985) support this point as they state that the withdrawal of male labour from the peasant subsistence production intensified female labour and led to reduction in cultivated subsistence food crop acreage. This meant that women suffered general psychological stress, fatigue and poor health due to overworking (Grey \& Patel, 2015). In addition, 49 (72.1\%) of the respondents also mention that the European labour laws compromised Agikuyu women's wellbeing due to physical and sexual abuse which were often committed by men (Table 3). Therefore, due to this intensification of Agikuyu women responsibilities, some of the indigenous labour-intensive food crop production like rigorous selection of seed varieties for planting, intensive weed control, soil erosion conservation practices, shifting cultivation, crop rotation farm fallowing, slash and 
burn and harvesting and storage were slowly neglected and underutilized. Other lied dormant as if they are extinct due to changing conditions Lunga \& Musaruwa (2016).

Twenty-two (32.4\%) of the respondents felt that that the colonial forced labour excluded most of the Agikuyu women from wage labour, paid them low wages and imposed taxes on them (Table, 3). The European colonialist exploited cheap female labour as women were being paid very low wages compared to their male counterpart, and they worked under very poor living and working conditions. This resulted to marginalization of the Agikuyu women as Sorrenson (1967) and Pala (1974) reiterate that until mid 1940s there were 23,354 men and only 5,535 women workers in Nairobi. They concluded that it is economically unrewarding for a country to deprive women access to monetary income in the homes and from the farms because it made women to be economically dependent on their male counterpart

\subsection{Implication of the European Commercial Crops on AWIKS in Food Crop Production}

The colonial administrators through Sir John Ainsworth founded the East African Agriculture and Horticulture society (EAAHS) in 1901 with the aim of promoting the growing crop diversification. He introduced cash crops such as tea, cotton, coffee and later pyrethrum, and commercial farming where they were to engage themselves in growing cash crops for export (KNA/MA1/12/1903). Therefore, the then British Commissioner Sir Charles Eliot encouraged settlers to grow a variety of cash crops and food crops for export because the production of indigenous food crops alone could not pay for administrative costs and make the protectorate economically viable (Huxley, 1968; Elkins, 2005). The diversification of crops production in Kiambu had significant implications on the Agikuyu women indigenous knowledge systems.

At the beginning of the European colonialism in Kiambu, the Agikuyu people were encouraged by the European to grow food crops for export in order to earn money to improve their standard of living (KNA/MA1/16/1911). The promotion of the new crops was linked to changes in crop production and general land management, specifically a move towards intensified monocropping and the abandonment traditional shifting and rotational farming (Waller, 2012). The commercialization of agriculture during the early colonial period in Kenya especially in Kiambu pushed the Africans to produce commodities that they did rarely consume. This affected their capacity for household autonomy and self-sufficient food crop production such that the acreage under coffee farms in Kiambu had risen from 600 in 1907 to 10,000 acres by the end of 1914 (Cowen, 1981)

From 1904 Africans were not allowed to grow commercial food crops and cash crops in the pretext that they could not manage growing them properly and that could lead to the spread of crop diseases in settlers' farms (Kitching, 1980). However, it was clear that the Europeans feared African competition in the production of cash crops therefore, at this time the commercial agricultural output for the African was minimal compared with the Europeans. Therefore, the period between 1903 and 1918 was one of expansion for settlers' commercial food and cash crop agriculture (Huxley, 1968). The settlers believed that their economic interests were to be safeguarded by keeping Africans under firm control. 


\section{MInstitute ${ }_{\text {Int }}^{\text {Macrothink }}$}

The introduction of cash crop farming distorted the existing traditional food crop production systems and as a result it affected the AWIKS on food crop production. Sixty three $(92.6 \%)$ of the respondents viewed that when the European established experimental cash crop farms for coffee and tea in Kiambu area, the Agikuyu people were restricted from growing such cash crops (Table 4). Ndangwa, (2017) observed that settlers introduced commercial agriculture on a large scale, foreign cash crops for export to the Western markets, that added strain on the local eco-system. Furthermore, the traditional food crop diversity declined in the early twentieth century due to replacement of local varieties by genetically uniform High Yield Varieties (HYVs) and fast-growing commercial food crops (FAO 2016).

Table 4. Implication of cash crops and European farming methods on AWIKS on food crop production

\begin{tabular}{|l|c|c|}
\hline Change & Frequency & Percent \\
\hline Restricted African farming & 63 & 92.6 \\
\hline $\begin{array}{l}\text { Introduction of monoculture (single) cash and food crops } \\
\text { plantations }\end{array}$ & 37 & 54.4 \\
\hline Large scale mixed farming & 25 & 36.8 \\
\hline Introduction of new farm implements & 41 & 89.7 \\
\hline Distribution of new crop seeds variety & 13 & 61.8 \\
\hline Training of African agricultural instructions & 68 & 100 \\
\hline Total interviews conducted & Frequency & Percent \\
\hline Effect on AWIKS & 52 & 76.5 \\
\hline Marginalization of traditional food crops & 29 & 42.6 \\
\hline Reduction in utilization of AWIKS on food crop production & 33 & 48.5 \\
\hline Decline in transmission of AWIKS on food crop production & 22 & 32.4 \\
\hline Restriction in use of AWIKS on food crop production & 68 & 100 \\
\hline Total interviews conducted & & \\
\hline
\end{tabular}

The European restriction of Africans from Cash Crop production and the neglect of domestic food production had some implications on the AWIKS on food crop production. Although the Agikuyu women continued to grow some of their indigenous food crops using their indigenous knowledge systems and skills, 52 (76.5\%) of the respondents stated that some of the food crops they used to grow which needed a lot of attention, time and care. Most of the traditional food crops were drought resistance like the traditional colored kikuyu maize, millet and sorghum, tuber crops, cassava, yams were slowly being neglected (Table 4). Lunga \& Musaruwa (2016) pointed out that colonial agriculture largely destroyed traditional structures since it dictated what natives could grow not to grow to give settlers a competitive advantage.

A variety of traditional cereals that were drought resistant were replaced with flat Hickory King-white grade maize, English (Irish) potatoes, carrots, Rose coco beans and kidney beans that were viewed as fast growing, high yielding varieties and commercially viable were 
mainly introduced as cash crops and were important because of their dual role as food and cash crops (Kitching, 1980). The commercial crop production was intended for meeting British demands especially during First World War time food shortages. The new market system required competition for resources and export of both cash and food crops. Therefore the price for the Hickory King-White maize was higher than the traditional maize (mbembe ya githigu), it also replaced drought-resistant sorghum and millet as the staple crop grown both seasons which made the Africans to become more vulnerable to inevitable drought events (Alila 1977; Overton 1987).

According to Kiambu District Annual report 1912-1913, one Indian shop exported from Limuru 20 tons of Hickory King-white grade maize in one month (KNA/MA1/12/4, 1912-1913). The Europeans argued that the new maize and bean variety had a shorter growing season than the traditional food crops and could be exported to South African ready market. Twenty nine (29) (42.6\%) of the respondents stated that as a result of marginalization of some labour intensive traditional food crops, there was a significant reduction in use of AWIKS on food crop production (Table 4). For example, the Chiefs, Headmen and Agricultural Instructors were initially distributing the seeds for these new crops freely to the local people but later the local people were to buy them from Indian shops (Wamoro wa Nderi, O.I 2017). However, Nancy \& Katherin (2008) reported that the new food crops that were brought by the European settlers were generally readily accepted by the indigenous people and were quickly adopted into their food crop production systems. They say that these new crops alone did not cause the demise of traditional food, but they initiated the process of underutilization and neglect of AWIKS. Colonialism undermined the decisions of the indigenous people and they were forced to slowly adapt the knowledge system that was in line with changing conditions and make their own contributions (Grey \& Patel, 2015)

Moreover, $37(54.4 \%)$ and $25(36.8 \%)$ of the respondents indicated that the European government also established large scale single crop plantations (monoculture) and large scale mixed farming of cash crops and of livestock production for commercial purpose and the domestic food crop production was slowly being neglected (Table 4). To this extent, the crop production was more diversified during the early colonial period because the colonial government was very anxious to modernize agricultural production in order to realize profit. However, Verena \& Cheema (2007) pointed out that during the establishment of the large scale plantations of coffee, tea, pyrethrum and Hickory King-white maize, numerous indigenous food crop species were destroyed or were no longer available because their habitants were destroyed or cleared for commercial agriculture (ecological damage). FAO estimated that $75 \%$ of the world's food crop diversity was lost in the twentieth century due to replacement of local varieties by genetically uniform high yield varieties and fast growing commercial food crops (FAO 2016).

The European colonialist encouraged the Agikuyu people to plant these crops especially the Hickory- King (white maize) in straight lines and to avoid mixed cropping for better yield. This was a change from the traditional set up where the Agikuyu women were using mixed cropping in order retain soil moisture. This indigenous knowledge was very effective in meeting their food requirements, in areas of land clearing, sowing, harvesting, weeding, 
fallow farming, mixed cropping, intercropping, crop rotation etc. helped tremendously in their bumper harvest. Indigenous crops of a particular area played a vital role in food security (Jiri et al., 2016). Other crops that were gaining popularity because of the ready market in towns were onions, carrots and a variety of vegetables such as kales and cabbage which were being grown at Kabete, Limuru and Upland near escarpment on the edge of the Agikuyu reserves.

The modern crop production methods slowly displaced the indigenous drought resistance crops such as millet, cassava, arrowroots, yams that were also very reach in nutrients. The traditional varieties of cereals such as millet and Sorghum were grown to ensure food security (Lunga \& Musaruwa, 2016). However, according to the respondents, the Agikuyu people were still finding it difficult to adopt the new single crop farming because they were seeing it as very tedious, that its single plant could take too much land at the expense of other food crops, and therefore the method could compromise the food supply in households.

During the first and second decades of colonial rule, the traditional agricultural seasonal calendar generally remained the same and it was still based on the rainfall patterns of the year. However, the food crop production patterns were changing in order to accommodate the new commercial crops (Kitching, 1980). The shift towards large-scale monoculture and large scale mixed farming may have led to systematic loss of indigenous food crop variety which demanded a lot of time and did not have a lot of commercial value. This implied that the process of erosion of indigenous agricultural practices and loss of AWIKS continued and the Agikuyu women could no longer use effectively the indigenous knowledge and skills on food crop production. Hence, the introduction of cash crop farming played a major role in undermining, marginalizing, neglecting and underutilization of the AWIKS on food crop production that was used to enhance availability of food in the household.

Furthermore, $61(89.7 \%)$ of the respondents mentioned that the European colonialism introduced new farming implements and skills such as the use of Jembe, ox-drawn ploughs and tractors for ploughing, farming machines, use of fertilizers and chemical pesticides. Further, 42 (61.8) of the respondents stated that the Europeans encouraged the Agikuyu people to use the new seeds that being imported from Europe and from South Africa by the government and were being provided to the Agikuyu farmers (Table 4). The idea of providing the Agikuyu farmers with variety of seeds from Europe and South Africa pushed to the periphery the women's indigenous knowledge and skills in selecting the best and healthy food crop seeds for planting.

From the onset the European viewed the individual planting of indigenous crops using indigenous Agikuyu women's traditional farm implements such as the digging stick muro as barbaric and uneconomical form of agricultural production. According to Njehia (O.I 2017), the Agikuyu Agricultural Instructors were being taught the new European western farming techniques at Kabete by extension Officers then they were posted to the reserves to manage and supervise various demonstration farms. The training took two years and no traditional food crop production knowledge and skills was incorporated during that training and in some areas like in Limuru tea plantation farms, the Europeans banned the use of traditional 
agricultural knowledge and practices (KNA/MA1/12/10, 1914-1915). Colonialism came with modern technology and introduced modern chemical pesticides, which were not kind to the environments because the usage of pesticides and fungicides on crops added strain on the local eco-system (Ndangwa, 2017).

However, it is important to note that while the new European agricultural implements and mechanization were meant to increase crop production for commercial purpose, they had far reaching changes in Agikuyu society. The new farm implements and technology such as ploughs and use of fertilizer were very expensive, the majority of the Agikuyu farmers in Kiambu could not afford to use them, and only a few wealthy farmers, clans, chiefs and headmen could purchase one collectively (Dilley, 1966). Therefore, even with the introduction of the new farming mechanization the Agukuyu women may have continued to use their traditional farming tools and technology which they were using prior to European colonialism due to lack of money to buy the new European tools and still the land in the reserves and squatter plots was too small.

\section{Conclusion}

From the findings of this study, it is clear that the first two decades of the establishment colonial rule in Kenya had significant implications on the AWIKS in food crop production. From the beginning, the European colonialist ignored the Agikuyu way of life and they were able instilled in the minds of the indigenous people that the practices were primitive and backward. Land alienation, new large-scale cash crop and food crop farming and introduction of forced labour slowly marked the beginning of transition from the subsistence food crop production to cash and food crops that had more economic value and utility. The Agikuyu women were forced to partly abandon their indigenous agricultural systems in order to fit in the European Capitalist economic policies. Moreover, the Agikuyu women were integrated into the colonial capitalist economy as secondary participants and their important role in proper use of indigenous knowledge systems on food crop production was not recognised and not integrated in the European commercial production. They also did not have enough time to utilize fully their indigenous knowledge systems on food crop production. They lost touch with some of the AWIKS for long leading to considerable generational and knowledge transmission breakdown. The women's adaption of European capitalist economic practices, the modern farming methods and technology led to neglect of indigenous food crop production, which implied that the AWIKS in production of such crops was not properly utilized to enhance food supply in the households hence the society became more vulnerable to drought and famine.

\section{References}

Agricultural Sector Development Support Programme (ASDSP). (2013). Retrieved from www.asdsp.co.ke/index.../Kiambu-County

Alila, P. (1977). Kenyan Agricultural Policy: The Colonial Roots of African Smallholder Agricultural Policy and Services. Working Paper no. 327. University of Nairobi.“Akamba 
Proverbs of Kenya." Retrieved January 16, 2019, from http://allthingskenyan.com/proverbs/proverbs-akamba.html

Anderson, D. (2017). Making the Loyalist Bargain: Surrender, Amnesty and Impunity in Kenya's Decolonization, 1952-63. The International History Review, 39(1), 48-70. https://doi.org/10.1080/07075332.2016.1230769

Ashley, D. (2000). Why Agriculture Development Projects have failed in Sierra Leone: Local Farmers Indigenous Knowledge the Missing Element. Indigenous Knowledge and Development Monitor, 8(1), 19-20.

Biggs, B., Duncan, E., Wales, J., Boruff, N., \& Bruce, E. (2018). Geographic Information and Communication Technologies for Supporting Smallholder Agriculture and Climate Resilience Climate. Journal of climate, (6), 97. https://doi.org/10.3390/cli6040097

Boserup, E. (1970). Women's Role in Economic Development. London: Taylor \& Francis Ltd.

Brett, E. (1973). Colonialism and underdevelopment in east Africa: The politics of economic change, 1919-1939. New York: NOK Publishers.

Brokensha, D., \& Warren, D. (1980). Indigenous Knowledge Systems and Development. Lanham: University Press of America.

Bryceson, D. (1980). Changes in peasant food production and food supply in relation to the historical development of commodity production in pre - colonial and colonial Tanganyika. The Journal of Peasant Studies, 7(2), 281-311. https://doi.org/10.1080/03066158008438107

Chikaire, J., \& Ajaero, O. (2018). Relevance of Indigenous Knowledge in Weather and Climate Forecast for planning farm activities in Imo State, Nigeria. Journal of Agricultural Research \& Technology, 19(1), 3-4. https://doi.org/10.19080/ARTOAJ.2018.19.556082

Clayton, A., \& Savage, D. (1974). Government and Labour in Kenya, 1895-1963. London: Frank Cass.

Cowen, M. (1981). Commodity Production in Kenyaes Central Province. Heyer Judith, Roberts Pepe and Williams Gavin (eds.) Rural Development in Tropical Africa. London, Macmillan. https://doi.org/10.1007/978-1-349-05318-6_5

Davison, J. (1988). Land and Women's Agricultural Production: The Context. Agriculture, Women and Land: The African Experience (ed.) London, Boulder and London: Westview Press.

Dilley, M. (1937). British Policy in Kenya Colony. New York, Connecticut college.

Donna, B. (2013). Qualitative Interviews; When Enough is Enough. Qualitative Market Research. Retrieved from www.researchbydesign.com.au

Elkins, C. (2005). Britain's Gulag: The Brutal End of Empire in Kenya. London: Jonathan Cape. 
Esese, D. (1990). Agricultural and Socio-Economic Change Among the Wanga of Mumias Division: 1860-1945 (Unpublished master's thesis). Kenyatta University.

Food Agriculture Organization (FAO). (2013). The State of Food Insecurity in the World: The multiple dimensions of food security. Retrieved from www.fao.org/publications/sofi/en/

Food and Agricultural Organization (FAO). (2016). The State of Food and Agriculture, Climate Change, Agriculture and Food Security. Food and Agriculture Organization of the United Nations Rome. Retrieved from www.fao.org

Gachihi, M. (1986). The Role of Kikuyu Women in The Mau Mau. M.A. Thesis, University of Nairobi.

Gakuru, O. (1992). Class and Pre-school Education in Kenya; P.H.D. Thesis, University of Nairobi.

Glass, G., \& Hopkins, D. (1996). Basic Statistics for the Behavioral Sciences, Allyn and Bacon. Toronto.

Grey. S., \& Patel, R. (2015). Food sovereignty as decolonization: Some contributions From Indigenous movements to food system and development politics. Journal of Agriculture and Human Values, 32(3), 431-444. https://doi.org/10.1007/s10460-014-9548-9

Hobley, C. (1910). Bantu Beliefs and Magic with Particular Reference to the Kikuyu and Kamba Tribe of Kenya Colony: Together with Some Reflections on East Africa After the War; Nairobi: KLB.

Hopkins, A. (1973). An economic history of West Africa. London: Longman.

Huxley, E. (1968). The Whiteman's Country Lord Delamere, and The Making of Kenya. New York, Praeger.

International Fund for Agriculture Development (IFAD). (2009). IFAD Policy on Engagement with Indigenous Peoples. Retrieved May 27, 2016, from http://www.ifad.org/english/indigenous/documents/p_policy_e.pdf

Jacquelin-Andersen, P. (Ed.). (2018). The Indigenous World 2018. The authors and The International Work Group for Indigenous Affairs. Copenhagen, Denmark.

Jiri, O., Mafongoya, P., Mubaya, C., \& Mafongoya, O. (2016). Seasonal climate prediction and adaptation using indigenous knowledge systems in agriculture systems in southern Africa: A review. Journal of Agricultural Science, 8(5), 156-172. https://doi.org/10.5539/jas.v8n5p156

Kanogo, T. (1993). Squatters and roots of Mau Mau. 1905-63. Nairobi: Heinemann.

Kanogo, T. (2005). African Womanhood in Colonial Kenya 1900-1950. Oxford: James Currey.

Kathuri, \& Pal, D. (1993). An introduction to Educational Research. Njoro; Egerton University Educational Media Centre. 
Kenya National Bureau of Statistics (KNBS). (2015). Kenya Population and Housing Census (KPHC) of 2009. Retrieved August 24, 2016, from www.knbs.or.ke

Kenyatta, J. (1965). Facing Mt. Kenya: the tribal life of the Gikuyu. New York: Vintage Books.

Kinoti, H. (1983). Aspects of Gikuyu Traditional Morallity. Ph.D, University of Nairobi.

Kitching, G. (1980). Class and Economic Change in Kenya: The Making of an African Petite Bourgeoisie, 1905-1970. London: Yale University press.

Kothari, C. (1985). Research Methodology: Methods and Techniques. New Delhi: Willey Eastern Ltd.

Leys, C. (1975). Under Development in Kenya; the Political Economy of Neo-Colonialism 1964 - 1971. London: Heinemann.

Lunga, W., \& Musaruawa, C. (2016). Exploiting Indigenous Knowledge Commonwealth to Mitigate Disaster; From the Archives of Vulnerable Zimbabwe. Indian Journal of Traditional Knowledge, 15(1), 22-29.

Mafongoya, P., \& Ajayi, O. (Ed.). (2017). Indigenous Knowledge Systems and Climate Change Management in Africa. CTA, Wageningen, The Netherlands.

Mbilinyi, M. (1984). Research Priorities in Women Studies in Eastern Africa. Women Studies International Forum, 7(4), 289-300. https://doi.org/10.1016/0277-5395(84)90054-2

McGregor. R. (1996). Kenya From Within: A Short Political History. London: Frank Cass and Company Ltd.

Middleton. J. (1953). The Kikuyu and Kamba of Kenya the Ethnography Survey of Africa, East and Central Africa. London: International Africa Institute.

Mies, M. (1986). Patriarchy and Accumulation on a World Scale. London: Zed Books.

Miller, D. (2012). Recommended sample size table to achieve data saturation. In: Donna Bonde. Qualitative Interviews; When Enough is Enough. Qualitative Market Research. Retrieved from www.researchbydesign.com.au

Musalia, M. (2010). Gender Relations and Food Crop Production: A Case of Kiambu District Kenya, 1920-1985 (Unpublished doctoral dissertation). Kenyatta University, Nairobi, Kenya.

Nasimiyu, R. (1985). Women in Colonial Economy of Bungoma: Role of Women in Agriculture 1902- 1960 .

Ndangwa, N. (2017). Indigenous Knowledge Systems and Their Relevance for Sustainable Development: A Case of Southern Africa. Sustainable Development: Relevance for Africa, (1), 167-172.

Olenja, J. M. (1991). Gender and Agricultural Production in Samia, Kenya: Strategies and Constraints. Journal of Asian and African Studies, 26(3-4), 267-275. https://doi.org/10.1177/002190969102600307 
Omwonyo, S. (1990). The Colonial Transformation of Gusii Agriculture (Unpublished doctoral dissertation). Kenyatta University, Nairobi, Kenya.

Overton, J. (1987). The Colonial State and Spatial Differentiation: Kenya, 1895-1920. J Hist Geog, 13(3), 267-282. https://doi.org/10.1016/S0305-7488(87)80115-9

Pala, I. (1981). Changes in Economic Ideology; A Study of the Joluo of Kenya with Special Reference to Women. Cambridge: Harvard University.

Peet, R., \& Hartwick, E. (1999). Theories of development. New York: Guilford Press.

Presley, C. (1992). Labour Unrest Among Kikuyu Women in Colonial Kenya in Women and Class in Africa (eds.) Robertson Claire and Berger Iris New York, London, Africana Publishing Company.

Rathgeber, E. (1990). WID, WAD and GAD; Trends in 'Research and Practice'. Journal of Development Areas, 24, 489. Retrieved from https://idlbnc.idrec.ca/dspace/bitstream/10625/5225/1/34345.pdf

Rosberg, C., \& Nottingham, J. (1966). The Myth of "Mau Mau" in Kenya. Nairobi: East African Publishing House.

Sorrenson, M. (1967).Land in the Kikuyu Country, A Study in Government Policy. Nairobi: OPU.

Staudt, K. (1988). Women Farmers in Africa: Research and Institutional Action, 1972-1987. Canadian Journal of African Studies, 22(3). https://doi.org/10.2307/485955

Tignor, R. (1976). The colonial Transformation of Kenya: The Kamba, Kikuyu, and Maasai from 1900 to 1939. London: Princeton.

Turner, N., \& Katherine, T. (2006) Where Women used to get Food" Cumulative Effects and Lossof Ethnobotanical Knowledge \& Practice. A case Study from Coastal British Columbia. Victoria, Victoria BCV.

Verena, R., \& Cheema, B. (2007). Colonization, the New World Order, and the eradication of traditional food habits in East Africa: historical perspective on the nutrition transition. Public Health Nutrition, 11(7), 662-674. https://doi.org/10.1017/S1368980007001140

Visvanathan, N. (1997). The Women, Gender, and Development Reader. London: Zed Books. Waller, R. (2012). Pastoral Production in Colonial Kenya: Lessons from the Past? Afr Studies $R, 55(2), 1-27$. https://doi.org/10.1353/arw.2012.0039

Warren, D. (1991). Using indigenous knowledge in Agricultural Development, World Bank Discussion paper no. 127.

Wolff, R. (1974). Britain and Kenya, 1870-1930: The economics of colonialism. Nairobi, Kenya: Transafrica Publishers. 
Wright, M. (1994). The Retention and Care of Seeds by Small Scale Farmers. United Kingdom: Natural Resource Institute.

Yonah, N., \& Gaoshebe, T. (2014). Rural Women Subsistence Farmers, Indigenous Knowledge System and Agricultural Research in South Africa. Journal of Hum. Ecol, 48(1), 33-4. https://doi.org/10.1080/09709274.2014.11906772

Zeleza, T. (1993). A Modern Economic History of Africa, Vol. 1: The Nineteenth Century.

Archival Sources (Kenya National Archives, KNA)

KNA/MA1/16/8, 1890-1916 Political Record Book, Kiambu Administration History KNA/MA1/7/12/1903 Itoka-Githunguri

KNA/MA1/7/13, 1903-1911 Political Record Book -Kiambu District

KNA/MA1/16/37, 1909-1917 Political Record Book -Kiambu District

KNA/Native Labour Commission, 1910-1912 Evidence and Report, Nairobi

KNA/PC/CP/4/3/2, 1911 Central Province Annual Report

KNA/MA1/16/14, 1911 Political Record Book -Kiambu District

KNA/MA1/16/20, 1911-1912 Political Record Book -Kiambu District

KNA/ MA1/1/14 Economic Survey Proper

KNA/PC/CP/4/1/2, 1912 Central Province Annual Report

KNA/MA1/12/10, 1914-1915 Kiambu Annual Report and Handing over Report

KNA/MA1/12/11, 1915-1916 Kiambu Annual Report and Handing over Report

KNA/AR/273/KBU, 1915-1916 Dagoretti Political Record Book

KNA/MA1/12/14, 1918-1919 Kiambu Annual Report and Handing over Report

KNA/MA1/12/16, 1920-1921 Kiambu Annual Report and Handing over Report

KNA/MA1/12/17, 1922 Kiambu Annual Report and Handing over Report 
Oral Sources

\begin{tabular}{|c|c|c|c|c|c|c|c|c|c|c|}
\hline Name & Sub-County & Date & Age & G & Name & Sub-County & Date & & age & G \\
\hline James Mwangi & Lari & $\begin{array}{l}23^{\text {rd }} \text { June } \\
2017\end{array}$ & 80 & M & Zippora Wariaga & Kikuyu & $\begin{array}{l}3^{\text {rd }} \\
2017\end{array}$ & Nov & 66 & $\mathrm{~F}$ \\
\hline Virginia Wanjugu & Lari & $\begin{array}{ll}26^{\text {th }} & \text { Jan } \\
2018 & \end{array}$ & 78 & $\mathrm{~F}$ & Francis Ngumo & Lari & $\begin{array}{l}26^{\text {th }} \\
2018\end{array}$ & Jan & 69 & M \\
\hline Teresa Waithera & Lari & $\begin{array}{ll}5 \text { th } & \text { Feb } \\
2018 & \end{array}$ & 67 & $\mathrm{~F}$ & Waithaka Njuguna & Kikuyu & $\begin{array}{l}21 \mathrm{st} \\
2018\end{array}$ & & 87 & M \\
\hline Hanna Kanyuira & Limuru & $\begin{array}{l}\text { 22nd Sep } \\
2017\end{array}$ & 81 & M & Martin Kinuthia & Lari & $\begin{array}{l}27 \text { th } \\
2017\end{array}$ & Sep & 76 & M \\
\hline Muturi Gathecha & Limuru & $\begin{array}{l}19^{\text {th }} \text { July } \\
2017\end{array}$ & 78 & M & Mary Wanjugu & Limuru & $\begin{array}{l}1 \mathrm{st} \\
2017\end{array}$ & Oct & 67 & $\mathrm{~F}$ \\
\hline Wamoro Wa Nderi & Lari & $\begin{array}{l}16^{\text {th }} \text { June } \\
2017\end{array}$ & 91 & $\mathrm{~F}$ & Felista Wachinga & Kikuyu & $\begin{array}{l}7^{\text {th }} \\
2017\end{array}$ & Sep & 67 & $\mathrm{~F}$ \\
\hline Phideris Ng'ang'a & Limuru & $\begin{array}{l}29^{\text {th }} \text { July } \\
2017\end{array}$ & 78 & $\mathrm{~F}$ & Hezra Njehia & Kikuyu & $\begin{array}{l}22^{\text {nd }} \\
2017\end{array}$ & Sep & 101 & M \\
\hline Muthongu Mbiyu & Limuru & $\begin{array}{l}4^{\text {th }} \text { Dec } \\
2017\end{array}$ & 72 & M & Elastus Muraya & Lari & $\begin{array}{l}12^{\text {th }} \\
017\end{array}$ & June & 100 & M \\
\hline
\end{tabular}

\section{Copyright Disclaimer}

Copyright reserved by the author(s).

This article is an open-access article distributed under the terms and conditions of the Creative Commons Attribution license (http://creativecommons.org/licenses/by/3.0/). 